Print ISSN: 2288-4637 / Online ISSN 2288-4645

doi:10.13106/jafeb.2019.vol6.no3.215

\title{
The Effect of Local Foods on Tourists' Recommendations and Revisit Intentions: The Case in Ho Chi Minh City, Vietnam
}

\author{
Ha Minh NGUYEN ${ }^{1}$, Linh Ai Thi DANG ${ }^{2}$, Trung Thanh NGO $^{3}$ \\ Received: June 4, 2019 Revised: June 14, 2019 Accepted: July 3, 2019
}

\begin{abstract}
The study aims to investigate the recommendation and revisit intentions of foreign tourists in Ho Chi Minh city, Vietnam through their satisfaction with local foods. The study proposed the group of five attributes for food image: taste, health concern, price, serving style, vendor/ restaurant staffs. The relationship between these attributes of food image and food satisfaction, as well as the one between food satisfaction and behavioral intentions were investigated. To ensure a high ratio of answers, a face-to-face survey was conducted in famous places at Ho Chi Minh city. Data with 210 foreign tourists. The study uses the methods of descriptive statistics, EFA, Cronbach Alpha and regression. The results showed that Five attributes of food image were chosen for the research, being taste, health concern, price, serving style and vendors/ restaurant staffs. All of these attributes showed a positive relationship with satisfaction. Among five factors, taste had the most impact on food satisfaction. Through the analysis of several attributes of food images, this study provides managerial implications for tourism marketers in researching the positive influence of food image on tourists' satisfaction which leads to their positive word-of-mouth and return to the tourism place.
\end{abstract}

Keywords: Food Image, Satisfaction, Recommendation, Revisit Intention.

JEL Classification Code: M31, L83, Z32, Q56.

\section{Introduction}

Tourism is now considered as a driving force for regional development by increasing destinations' receipts, income, employment and government revenues (Chen \& Tsai, 2007), especially in developing countries where it has created significant impacts on people and social life. Tourism also provides "enjoyment, variety, respite and amusement" to traveler makers (Jaiswal, Sapra, Patil, \& Lama, 2013). Many new trends of tourism have been developed for the recent years, which food tourism plays an irreplaceable role.

1 First Author and Corresponding Author. Associate Professor, Ho Chi Minh City Open University, Vietnam [Postal Address: 97 Vo Van Tan Street, Ward 6, District 3, Ho Chi Minh City 700000, Vietnam]. Email: ha.nm@ou.edu.vn

2 MBA, International University, Ho Chi Minh City, Vietnam.

3 MBA, Ho Chi Minh City Open University, Vietnam.

Email: trung.nt@ou.edu.vn

(- Copyright: Korean Distribution Science Association (KODISA)

This is an Open Access article distributed under the terms of the Creative Commons Atrribution NonCommercial License (https://creativecommons.org/licenses/by-nc/4.0/) which permits unrestricted noncommercial use, distribution, and reproduction in any medium, provided the original work is properly cited.
According to the Global Report of United Nations World Tourism Organization (UNWTO) in 2012, food tourism, while obtaining a considerable growth and becoming the most dynamic and creative segment of tourism, allows the rural or developing communities to generate income and employment opportunities locally, as well as to empower others economic fields such as agriculture. There exists a highly close relationship between food and tourism, which have raised deep interest among researchers. Even though the visit purpose does not focus on food discovery and experience, all tourists must consume food during their trip (Chi, Chua, Othman, \& Karim, 2013). Food and its related factors are indispensable components in the overall traveling experience (Ardabili, Rasouli, Daryani, Molaie, \& Sharegi, 2011). Food tourists occupy a high percentage among tourist groups and while making decision for destination, local food plays a crucial role (Okumus \& Mckercher, 2007).

Nowadays, developing food aspects in tourism is put in high concern by travelers makers in many countries, which can be organized under festivals (e.g. Melbourne Food and 
Wine festival, New York Street Food Festival, ..) or developed into country's tourism slogan (e.g. "Malaysia Truly a Kitchen", "Thailand - Kitchen of the World", "Turkish Delight"...). In Vietnam, this concern has been already mentioned by Philip Kotler in 2009 during his visit in Ho Chi Minh city. His favor for Vietnam to become "the kitchen of the world" once again confirmed the importance role of food in various contributors of tourism of the country.

The study focused on the influence of food in tourist's satisfaction, recommendations and revisit intentions. Five attributes of food image were mentioned.

\section{Literature Review}

\subsection{Local Food}

In one side, according to Kim, Eves, and Scarles (2009), local food and beverages are produced in local places, which represent the local identity or brand. In the other side, Nummedal and Hall (2006) stated that local foods are not only "about locally grown products" but contains of outside ingredients and are made locally with local identity. More specifically, Sims (2009) clarified that local foods are products produced "within a 30 mile radius of the target market". Yurtseven and Kaya (2011) concluded that local food is the best representative of intangible heritage of the destination.

\subsection{Food in Tourism}

Food plays an important role in showing to tourists the traditions of the area through its tastes and flavors (Ryu \& Jang, 2006). Thus, it builds up a general image of the community that influences strongly the tourists' experiences. Food, as a fundamental of tourism's products, is considered as a more important attribute to destination attractiveness than "climate, accommodation and captivating scenery" (Zainal, Zali, \& Kassim, 2010). Local foods are great representatives of the community in terms of social, environmental, cultural, historical and economical aspects (Mitchell \& Hall, 2006). In addition, not only being the strong symbol of quality of life and authenticity, food plays the role of a representative of important theme used in advertisements (Frochot, 2003). Food tourism creates gastro brands for numerous countries and regions such as France, Italy, California... (Jaiswal et al., 2013). In developing countries (Vietnam, Mexico, Malaysia...), food plays the central role of the overall experience (Paul, 2010). In term of personal effect, food is obligatory energy source for body functions and also unique to influence tourists' "sensory pleasure" and their travel experience (Richards, 2002 as cited in Mak, Lumbers, \& Eves, 2012).

\subsection{Food Image}

While Kim and Eves (2012) concluded that this matter can be measured by food product and its uniqueness, place where to consume, style of serving food as well as how much to pay, Steptoe, Pollard, and Wardle (1995) focused on nine following factors: health, mood, convenience, sensory appeal, natural content, price, weight control, familiarity and ethical concern. Lertputtarak (2012) built a conceptual model with nineteen attributes for Thai food image, including of: a well-known/popular cuisine in the world, variety of food, food gives a culture experience, ingredients, tastiness, nourishing food, unique food, food hygiene, Thai herbs good for health, taste of Thai fruits, attractive food presentation, deliciousness, freshness, exotic cooking methods, variety of attractive restaurant types, unique serving style of restaurant staff, learning local eating habits and table manners, environment and unique style of decoration, reasonable price/value for money.

According to Kim and Eves (2012), food image can be divided into food product and service quality. Regarding food product, for Kivela, Inbakaran, and Reece (2000), it can be tested via taste, wide selection of menu and nutrition, whereas Young and Jang (2007) cited the food presentation, sanitation, taste, freshness and temperature. Besides of ingredients, Ardabili et al. (2011) also focused on the novelty or ordinariness of food.

\subsection{Recommendations and Revisit Intentions}

In marketing and tourism research, loyalty, the important vision of service providers, determines the level of long-term profits, rating by the high retention of customers (Zeithaml, Berry, \& Parasuraman, 1996). By Chen and Tsai (2007), revisit and recommendations intentions are one main attribute of tourists' behaviors or loyalty, together with destination's selection, perceived value or satisfaction. Recommendation intentions to other people are the "most often sought types of information" for tourists (Chi \& Qu, 2008). It plays a very important role in tourism marketing due to its reliability for potential tourists (Yoon \& Uysal, 2005).

\subsection{The Relationship between Food Image, Satisfaction, Recommendation and Revisit Intention}

The context of this study will focus mainly on five factors to answer the questions proposed: taste, health concern, price, serving style, vendors/restaurant staffs.

Taste: Among attributes of food image, taste takes the highest ranks, which creates a strong impact on food 
consumption satisfaction and behavior (Kim et al., 2011). Through the color, texture, freshness, food taste in general plays a significant role in food consumption experience of tourists (Gagic, Tesanovic, \& Jovicic, 2013). Taste of food with variety in menu enhances the overall tourist's satisfaction in the whole trip (Johns \& Pine, 2012). Specially, novelty in food tastes has been an outstanding factor while studying about food product quality. Besides the tastiness or freshness, novelty can be the first and the strongest impression of food in tourists. Mak et al. (2012) cited that traveling is synonymous with "otherness" that gives the sense of unfamiliarity and distinguishes cultures and origins. They consider that trying new foods can become an unforgettable part of their traveling experience (Ardabili et al., 2011).

\section{H1: Taste has positive influence on satisfaction.}

Health Concern: is now placed in high rank of the most concerned things relating to foods. Health concern is concerned while mentioning specific ingredients and flavors of the region, health risks, culinary setting (Cohen \& Avieli, 2004). Fear of illness becomes a doubt about foods in the visiting place (Ardabili et al., 2011). Short term effect such as stomachache or sick, and long term one caused by chemicals in food are strongly considered while choosing foods (Cohen, 1986). Sanitation does thus have strong impact on tourist's willingness to consume destination meals (Ardabili et al., 2011).

H2: Health concern has positive influence on satisfaction.

Price: The quality of the tourism product, including food, is measured through the value of daily price spent in the holiday (Al-Ababneh, 2013). The relationship between how much tourists have to pay for food with their satisfaction and behaviors intentions was found by Kim et al. (2011). By Gagic et al. (2013), the fairness in pricing critically influences tourists' satisfaction.

H3: Price has positive influence on satisfaction.

Serving Style: From nation to nation, with different cultures, the way of offering food vary and make difference between destinations, which leaves unforgettable memory to tourists about their trip (Okumus \& McKercher, 2007). Lerputtarak (2012) concluded that poor serving style disrupted the overall experience and satisfaction, as well as destroyed the destination reputation. The serving style (table manner, location, physical decoration, ambiance) has a significant effect in the overall satisfaction of customers (Gagic et al., 2013).
H4: Serving style has positive influence on satisfaction.

Vendors/ Restaurant Staffs: Vendors/restaurant staff attitudes is a studied factor as a very important point to measure the level of customer service and intercultural communication in tourism sector where people comes from many different cultures and nations (Coleman, 1998). This factor has a direct impact on both interior and exterior customer satisfaction (Ilbery, Saxena, \& Kneafsey, 2007).

H5: Vendors/ Restaurant staffs has positive influence on satisfaction.

Satisfaction, Recommendation and Revisit Intention: Chen and Tsai (2007), Choi and Chu (2001), Yoon and Uysal (2005) showed that tourist's satisfaction create both high recommendations tendency and revisit intention. Many other authors (Baker \& Crompton, 2000; Kozak, 2001; Jang \& Feng, 2007) focused on proving that the antecedent of recommendation and revisit intention is "tourists' satisfaction with travel experience". Baker and Crompton (2000) also presented a causal relationship between these factors. Regarding to them, the higher level of satisfaction would lead to an increase of revisit intention and greater accept in case of higher price. Thus, there would be an enhanced in destination's reputation, which creates strong impact in firsttime visitors through word-of-mouth and media strategies.

H6: Satisfaction has positive influence on recommendation and revisit intention.

\section{Research Methodology}

\subsection{Research Model}

A model framework is suggested as follows (Figure 1):

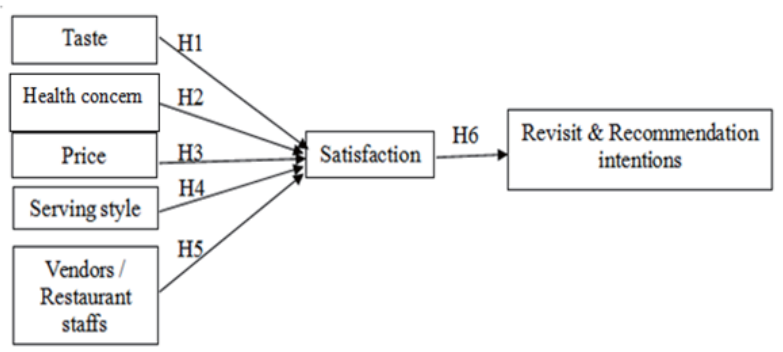

Figure 1: Model framework 


\subsection{Measurement Scale}

Independent Variables: The items of five independent variables (taste, health concern, price, serving style, vendors/ restaurant staffs) were set base on previous relating studies and measured by Five-point Likert scale as follows (Table 1):

Dependent Variables: the items of satisfaction, recommendation and revisit intentions are below (Table 2 ):

\subsection{Data}

To ensure a high ratio of answers, a face-to-face survey was conducted in famous places at Ho Chi Minh City where concentrates a big number of foreign tourists with various nationalities and tourism purposes. Many restaurants, hotels, cafeterias are located in these streets, where tourists spend time for relaxation or enjoying local food and beverage).

Table 1: Measurement scale for Independent variables

\begin{tabular}{|c|c|}
\hline Items & Previous studies \\
\hline \multicolumn{2}{|l|}{ Taste } \\
\hline \multicolumn{2}{|l|}{ TASTE1: Food is tasty } \\
\hline TASTE2: Food served is always fresh & \multirow{4}{*}{$\begin{array}{l}\text { Jaswal et al. (2013) } \\
\text { Kim \& Eves (2012) } \\
\text { Chi et al. (2013) }\end{array}$} \\
\hline TASTE3: Quality of food is consistent & \\
\hline TASTE4: Taste of local foods is unfamiliar with my eating routine & \\
\hline TASTE5: There is a variety of local food choices & \\
\hline \multicolumn{2}{|l|}{ Health concern } \\
\hline \multicolumn{2}{|l|}{ HEALTH1: I haven't had any unexpected illness caused by local foods during my trip } \\
\hline \multicolumn{2}{|l|}{ HEALTH2: Local foods contains of much nutritional ingredients } \\
\hline \multirow{2}{*}{\multicolumn{2}{|c|}{$\begin{array}{l}\text { HEALTH3: Lots of fresh local ingredients can be found in the local foods } \\
\text { HEALTH4: The way that food is prepared is clean }\end{array}$}} \\
\hline & \\
\hline \multicolumn{2}{|l|}{$\begin{array}{l}\text { HEALTH4: The way that food is prepared is clean } \\
\text { HEALTH5: The vendors/restaurant staffs are clean }\end{array}$} \\
\hline \multicolumn{2}{|l|}{ HEALTH6: Food place is in hygienic environment } \\
\hline \multicolumn{2}{|l|}{ Price } \\
\hline \multicolumn{2}{|l|}{ PRICE1: Price is reasonable } \\
\hline PRICE2: Food is worth of money & \multirow{3}{*}{$\begin{array}{l}\text { Tan et al. (2014) } \\
\text { Rahman et al. (2012) }\end{array}$} \\
\hline PRICE3: Billing is accurate & \\
\hline PRICE4: All customers are equally treated in term of price & \\
\hline \multicolumn{2}{|l|}{ Serving style } \\
\hline \multicolumn{2}{|l|}{ SERVING1: The food place is well located } \\
\hline SERVING2: Take away service is competent and efficient & \multirow{5}{*}{ Jaiswal et al. (2013) } \\
\hline SERVING3: Speed of service is maintained during busy time & \\
\hline SERVING4: I feel relaxed in the food house/restaurant & \\
\hline SERVING5: I am served exactly what I order & \\
\hline SERVING6: Table setting \& serving offer special experience & \\
\hline \multicolumn{2}{|l|}{ Vendors/ Restaurant Staffs } \\
\hline VENDOR1: Vendors/restaurant staffs are friendly & \multirow{5}{*}{$\begin{array}{l}\text { Sanchez et al. (2006) } \\
\text { Tan et al. (2014) } \\
\text { Chi et al. (2013) }\end{array}$} \\
\hline VENDOR2: Vendors/restaurant staffs assure to correct something wrong & \\
\hline VENDOR3: Vendors/restaurant staffs are willing to explain menu items, ingredients or method of cooking & \\
\hline VENDOR4: Vendors/restaurant staffs are sensitive to individual needs & \\
\hline VENDOR5: Vendors/restaurant staffs do not pressure me in decision making & \\
\hline
\end{tabular}

Table 2: Measurement scale for dependent variable

\begin{tabular}{|l|c|}
\hline \multicolumn{1}{|c|}{ Item } & Previous studies \\
\hline SATISFACTION: In which level is your overall satisfaction about local food in Ho Chi Minh city? & \\
\hline RECOMMEND1: How likely would you choose Ho Chi Minh city again for one of your upcoming trip? & Lertputtarak (2012) \\
\cline { 1 - 1 } $\begin{array}{l}\text { RECOMMEND2: How likely are you willing to recommend local foods in Ho Chi Minh city for your } \\
\text { families/friends/colleagues? }\end{array}$ & \\
\cline { 1 - 2 } $\begin{array}{l}\text { RECOMMEND3: How likely are you willing to recommend Ho Chi Minh city as a tourist destination for your } \\
\text { families/friends/colleagues? }\end{array}$ & \\
\hline
\end{tabular}


These relating conditions relating for participants are set: being foreigners, having experienced local foods in Ho Chi Minh city during the trip, understanding English. 210 questionnaires were distributed in around a month. Due to face-to-face interview where interviewer directly interacts with respondents during survey time, all 210 questionnaires were collected. Nine of them were unusable due to missing of information. 201 complete answers were valid and usable for data analysis. Thus, the response rate remains at $96.7 \%$.

\section{Results}

\subsection{Descriptive Statistics}

Below Table 3 shows that for:

Health: The overall mean of this factor is 3.17 , meaning that the majority of respondents feel satisfied with health concern of local foods.

Price: The overall mean of this factor is 3.26 , indicating a relatively high satisfaction level of tourists towards price of foods.

Vendor/ Restaurant staffs: The overall mean (3.16) indicates a quite high satisfaction level but is considered the smallest overall mean among independent variables.

Taste: The overall mean of this factor is the highest among independents ones (3.71).

Serving style: The overall mean of this factor is 3.54 , indicating a high satisfaction level of tourists.

Satisfaction and Recommendation and revisit intentions respectively have means at 3.20 and 3.01.

Table 3: Mean and Standard deviation

\begin{tabular}{|c|c|c|c|c|c|}
\hline & $\mathbf{N}$ & Minimum & Maximum & Mean & $\begin{array}{c}\text { Std. } \\
\text { Deviation }\end{array}$ \\
\hline HEALTH1 & 201 & 1 & 5 & 3.19 & 1.256 \\
\hline HEALTH2 & 201 & 1 & 5 & 3.30 & 1.225 \\
\hline HEALTH3 & 201 & 1 & 5 & 3.07 & 1.168 \\
\hline HEALTH4 & 201 & 1 & 5 & 3.23 & 1.044 \\
\hline HEALTH5 & 201 & 1 & 5 & 2.99 & 1.378 \\
\hline HEALTH6 & 201 & 1 & 5 & 3.24 & 1.093 \\
\hline PRICE1 & 201 & 1 & 5 & 3.17 & .955 \\
\hline PRICE2 & 201 & 1 & 5 & 3.36 & 1.115 \\
\hline PRICE3 & 201 & 1 & 5 & 3.26 & 1.037 \\
\hline PRICE4 & 201 & 1 & 5 & 3.26 & 1.051 \\
\hline VENDOR1 & 201 & 1 & 5 & 3.05 & .955 \\
\hline VENDOR2 & 201 & 1 & 5 & 3.40 & 1.040 \\
\hline VENDOR3 & 201 & 1 & 5 & 3.14 & .917 \\
\hline VENDOR4 & 201 & 1 & 5 & 2.86 & 1.036 \\
\hline VENDOR5 & 201 & 1 & 5 & 3.35 & 1.072 \\
\hline
\end{tabular}

\begin{tabular}{|c|c|c|c|c|c|}
\hline TASTE1 & 201 & 1 & 5 & 3.88 & 1.200 \\
\hline TASTE2 & 201 & 1 & 5 & 3.84 & 1.206 \\
\hline TASTE3 & 201 & 1 & 5 & 3.83 & 1.162 \\
\hline TASTE4 & 201 & 1 & 5 & 3.42 & 1.177 \\
\hline TASTE5 & 201 & 1 & 5 & 3.59 & 1.106 \\
\hline SERVING1 & 201 & 1 & 5 & 3.56 & 1.052 \\
\hline SERVING2 & 201 & 1 & 5 & 3.51 & .996 \\
\hline SERVING3 & 201 & 1 & 5 & 3.73 & 1.038 \\
\hline SERVING4 & 201 & 1 & 5 & 3.67 & 1.158 \\
\hline SERVING5 & 201 & 1 & 5 & 3.61 & 1.053 \\
\hline SERVING6 & 201 & 1 & 5 & 3.16 & .958 \\
\hline SATISFACTION & 201 & 1 & 5 & 3.20 & 1.123 \\
\hline RECOMMEND1 & 201 & 1 & 5 & 3.14 & 1.185 \\
\hline RECOMMEND2 & 201 & 1 & 5 & 3.05 & 1.117 \\
\hline RECOMMEND3 & 201 & 1 & 5 & 2.85 & 1.144 \\
\hline
\end{tabular}

\subsection{Cronbach's Alpha with Scales before EFA}

Taste: After first time of statistics running, Cronbach's Alpha (0.787) is acceptable (higher than 0.7). Item TASTE3 had Item-Total Correlation at $0.208(<0.3)$. Thus, TASTE3 was removed. After having removed TASTE3 (with Cronbach Alpha if item is deleted $=0.853$ ), new Cronbach's Alpha was 0.853 (acceptable). All items have Item-Total Correlation higher than 0.3 in Table 4.

Table 4: Result of Cronbach's Alpha analysis

\begin{tabular}{|c|c|c|c|c|}
\hline & & $\begin{array}{c}\text { Corrected Item- } \\
\text { Total } \\
\text { Correlation }\end{array}$ & $\begin{array}{l}\text { Cronbach's } \\
\text { Alpha if Item } \\
\text { Deleted }\end{array}$ & $\begin{array}{c}\text { Cronbach's } \\
\text { Alpha }\end{array}$ \\
\hline \multirow{4}{*}{ 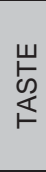 } & TASTE1 & .765 & .781 & \multirow{4}{*}{.853} \\
\hline & TASTE2 & .762 & .782 & \\
\hline & TASTE4 & .650 & .831 & \\
\hline & TASTE5 & .601 & .849 & \\
\hline \multirow{5}{*}{$\begin{array}{l}\stackrel{I}{\models} \\
\underset{⿱}{\amalg} \\
\text { Ш }\end{array}$} & HEALTH1 & .640 & .761 & \multirow{5}{*}{.811} \\
\hline & HEALTH2 & .631 & .764 & \\
\hline & HEALTH4 & .640 & .766 & \\
\hline & HEALTH5 & .580 & .784 & \\
\hline & HEALTH6 & .523 & .796 & \\
\hline \multirow{4}{*}{ 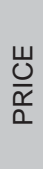 } & PRICE1 & .559 & .809 & \multirow{4}{*}{.820} \\
\hline & PRICE2 & .713 & .738 & \\
\hline & PRICE3 & .609 & .788 & \\
\hline & PRICE4 & .691 & .749 & \\
\hline \multirow{5}{*}{ 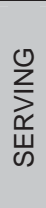 } & SERVING1 & .610 & .804 & \multirow{5}{*}{.832} \\
\hline & SERVING2 & .595 & .808 & \\
\hline & SERVING3 & .645 & .794 & \\
\hline & SERVING5 & .619 & .802 & \\
\hline & SERVING6 & .689 & .783 & \\
\hline
\end{tabular}




\begin{tabular}{|c|c|c|c|c|}
\hline \multirow{5}{*}{ 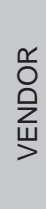 } & VENDOR1 & .687 & .825 & \multirow{5}{*}{.857} \\
\hline & VENDOR2 & .576 & .853 & \\
\hline & VENDOR3 & .743 & .812 & \\
\hline & VENDOR4 & .648 & .834 & \\
\hline & VENDOR5 & .726 & .814 & \\
\hline \multirow{3}{*}{ 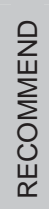 } & $\begin{array}{l}\text { RECOMME } \\
\text { ND1 }\end{array}$ & .666 & .659 & \multirow{3}{*}{.784} \\
\hline & $\begin{array}{l}\text { RECOMME } \\
\text { ND2 }\end{array}$ & .620 & .710 & \\
\hline & $\begin{array}{c}\text { RECOMME } \\
\text { ND3 }\end{array}$ & .584 & .748 & \\
\hline
\end{tabular}

Health: After first time of statistics running, Cronbach's Alpha (0.776) is acceptable (higher than 0.7). But item HEALTH3 had Item-Total Correlation at $0.225(<0.3)$. Thus, HEALTH3 was removed. After having removed HEALTH3 (with Cronbach Alpha if item is deleted $=0.811$ ), new Cronbach's Alpha was 0.811 (acceptable). All items have Item-Total Correlation higher than 0.3 in Table 4.

Price: After first time of statistics running, Cronbach's Alpha (0.820) is acceptable (higher than 0.7). All items have Item-Total Correlation higher than 0.3 in Table 4.

Serving style: After first time of statistics running, Cronbach's Alpha (0.775) is acceptable (higher than 0.7). But item SERVING4 had Item-Total Correlation at 0.175 (< 0.3). Thus, SERVING4 was removed. After having removed SERVING4 (with Cronbach Alpha if item is deleted $=0.832$ ), new Cronbach's Alpha was 0.832 (acceptable). All items have Item-Total Correlation higher than 0.3 in Table 4.

Vendors/ Restaurant staffs: After first time of statistics running, Cronbach's Alpha (0.857) is acceptable (higher than 0.7). All items have Item-Total Correlation higher than 0.3 in Table 4.

Recommend and Revisit intentions: After first time of statistics running, Cronbach's Alpha (0.784) is acceptable (higher than 0.7). All items have Item-Total Correlation higher than 0.3 in Table 4.

\subsection{Exploratory Factor Analysis (EFA)}

Independent Variables: The EFA was used to indicate the underlying dimensions of Food image and Satisfaction. For Food image, all factors had eigenvalue above 1.0, which explained $65.256 \%$ of the total variance. The rotated component matrix (Table 5) presented the factor structure with all items loaded on their designated dimensions. All variables provided sufficient explanation. The total variance explained by the five factor solution was relatively high at $65.256 \%$, indicating that these variables were highly related to each other. This result supported to measure the validity of measurement of the five attributes of the studied model.
Table 5: Rotated component matrix for independent variables

\begin{tabular}{|l|c|c|c|c|c|}
\hline & \multicolumn{5}{|c|}{ Component } \\
\hline & $\mathbf{1}$ & $\mathbf{2}$ & $\mathbf{3}$ & $\mathbf{4}$ & $\mathbf{5}$ \\
\hline VENDOR3 & .834 & & & & \\
\hline VENDOR5 & .752 & & & & \\
\hline VENDOR4 & .749 & & & & \\
\hline VENDOR1 & .740 & & & & \\
\hline VENDOR2 & .661 & & & & \\
\hline SERVING6 & & .818 & & & \\
\hline SERVING1 & & .765 & & & \\
\hline SERVING3 & & .756 & & & \\
\hline SERVING2 & & .746 & & & \\
\hline SERVING5 & & .737 & & & \\
\hline PRICE2 & & & .817 & & \\
\hline PRICE4 & & & .794 & & \\
\hline PRICE3 & & & .662 & & \\
\hline PRICE1 & & & .618 & & \\
\hline HEALTH4 & & & & .746 & \\
\hline HEALTH5 & & & & .745 & \\
\hline HEALTH2 & & & & .739 & \\
\hline HEALTH1 & & & & .698 & \\
\hline HEALTH6 & & & & .634 & \\
\hline TASTE5 & & & & & .801 \\
\hline TASTE1 & & & & & .753 \\
\hline TASTE2 & & & & & .751 \\
\hline TASTE4 & & & & & .694 \\
\hline
\end{tabular}

Five groups of factor were presented after the solution. Items of same factor were grouped into same group, meaning that these items were well used to define the factors:

Factor 1 (Vendor) includes variables: VENDOR3, VENDOR5, VENDOR4, VENDOR1, VENDOR2.

Factor 2 (Serving style) includes variables: SERVING6, SERVING1, SERVING3, SERVING2, SERVING5.

Factor 3 (Price) includes variables: PRICE2, PRICE4, PRICE1, PRICE3.

Factor 4 (Health) includes variables: HEALTH4, HEALTH5, HEALTH2, HEALTH1, HEALTH6.

Factor 5 (Taste) includes variables: TASTE5, TASTE1, TASTE2, TASTE4

Dependent variables: The KMO for overall value was 0.694 and Bartlett's test was significant at 0.00 . These numbers concluded that the data was suitable for factor analysis. For Recommend and revisit intentions, all factors had eigenvalue above 1.0 , which explained $69.846 \%$ of the total variance. Only one group was presented after the solution. Factor Recommend includes variables: RECOMMEND1, RECOMMEND2, RECOMMEND3. 


\subsection{Correlation Matrix}

In the first correlation, all correlations among variables were significant at $p<0.01$. Taste, Price and Health were highly correlated to Satisfaction (respectively $r=0.631$, $0.569,0.547)$.

\subsection{Regression Analysis}

\subsubsection{Testing Hypothesis $\mathrm{H} 1$ to $\mathrm{H} 5$}

The five main hypotheses were tested using hierarchical regression analysis. Taste was entered firstly, followed by Serving, Health, Price and Vendor.

The results show that the multiple correlation was quite high $(R=0.762)$. The adjusted $R 2$ was also relatively high magnitude $(R 2=0.581)$, indicating that a large proportion of the variability in satisfaction was accounted for by the multiple regression model. The first regression analysis showed the result of $\mathrm{R}$ square index at 0.581 , meaning that the regression of five independent variables has a vary of $58.1 \%$ of Satisfaction (Table 6).

Table 6: Coefficients of regression results

\begin{tabular}{|c|c|c|c|c|c|c|c|}
\hline & $\begin{array}{r}\text { Unstan } \\
\text { Coeff }\end{array}$ & $\begin{array}{l}\text { ardized } \\
\text { ients }\end{array}$ & $\begin{array}{l}\text { Standardized } \\
\text { Coefficients }\end{array}$ & \multirow{2}{*}{$t$} & \multirow{2}{*}{ Sig. } & \multicolumn{2}{|c|}{$\begin{array}{l}\text { Collinearity } \\
\text { Statistics }\end{array}$} \\
\hline & B & $\begin{array}{l}\text { Std. } \\
\text { Error }\end{array}$ & Beta & & & $\begin{array}{c}\text { Toleranc } \\
\mathrm{e}\end{array}$ & VIF \\
\hline (Constant) & -1.370 & .324 & & -4.229 & .000 & & \\
\hline VENDOR & .185 & .080 & .133 & 2.319 & .021 & .658 & 1.519 \\
\hline HEALTH & .310 & .066 & .251 & 4.673 & .000 & .743 & 1.345 \\
\hline SERVING & .154 & .069 & .108 & 2.244 & .026 & .921 & 1.086 \\
\hline PRICE & .279 & .077 & .209 & 3.649 & .000 & .659 & 1.518 \\
\hline TASTE & .418 & .067 & .363 & 6.209 & \begin{tabular}{|l|}
.000 \\
\end{tabular} & .628 & 1.592 \\
\hline
\end{tabular}

The regression coefficient was examined to observe these relationships. The result showed that Taste significantly influenced Satisfaction $(B=0.418, t=6.209)$. Thus, hypothesis 1 was supported. Health concern also show a significant influence on Satisfaction $(B=0.310$, $t=4.673$ ), which supported hypothesis 2. Satisfaction was also affected Price and Serving style (respectively $B=0.279$ and $0.154, \mathrm{t}=3.649$ and 2.244). Thus, hypothesis 3 and 4 were supported. Lastly, Vendors/ restaurant staffs also influenced the overall Satisfaction $(B=0.185, t=2.319)$ therefore hypothesis 5 was supported.

\subsubsection{Testing Hypothesis $\mathrm{H} 6$}

The regression analysis showed the result of $\mathrm{R}$ square index at 0.518 , meaning that the regression of Satisfaction has a vary of $51.8 \%$ of Recommendations and revisit intentions. The hypothesis 6 was also supported, indicated by $B=0.615$ and $t=14.616$ of Satisfaction (Table 7 ).

Table 7: Coefficients of regression results

\begin{tabular}{|c|c|c|c|c|c|c|c|}
\hline \multirow{2}{*}{ Model } & \multicolumn{2}{|c|}{\begin{tabular}{|c|} 
Unstandardized \\
Coefficients
\end{tabular}} & \multirow{2}{*}{$\begin{array}{c}\begin{array}{c}\text { Standardized } \\
\text { Coefficients }\end{array} \\
\text { Beta }\end{array}$} & \multirow{2}{*}{$t$} & \multirow{2}{*}{ Sig. } & \multicolumn{2}{|c|}{$\begin{array}{c}\text { Collinearity } \\
\text { Statistics }\end{array}$} \\
\hline & B & $\begin{array}{l}\text { Std. } \\
\text { Error }\end{array}$ & & & & Tolerance & VIF \\
\hline (Constant) & 1.047 & .143 & & 7.336 & .000 & & \\
\hline SATISFACTION & .615 & .042 & .720 & 14.616 & .000 & 1.000 & 1.000 \\
\hline
\end{tabular}

\subsubsection{Findings and Discussion}

This research presented the results regarding the factors affecting food satisfaction, recommendation and revisit intentions. And it also provided reliable scales to measure factors include taste, health concern, price, serving style and vendors/ restaurant staffs.

Taste: Regression result supported the hypothesis " $\mathrm{H} 1$ : Taste has positive influence on satisfaction", is consistent with previous researches of Lertputtarak (2012), Kim and Eves (2012), Namkung and Jang (2008). With the highest coefficient in the regression analysis, consistent with the conclusion of Lertputtarak(2012), taste contributes the most important role to the overall food satisfaction.

Health Concern: Regression result supported the hypothesis "H2: Health has positive influence on satisfaction", consistent with previous researches of Lertputtarak (2012), Steptoe et al. (1995), Namkung and Jang (2008). With the second highest coefficient (0.031) in the regression analysis, also consistent with the conclusion of Lertputtarak (2012), health contributes one of the most important roles to the overall food satisfaction.

Price: Regression results supported the hypothesis "H3: Price has positive influence on satisfaction", consistent with previous researches of Lertputtarak (2012), Steptoe et al. (1995), Kim and Eves (2012). A positive coefficient of price proves a positive relationship between this attribute with satisfaction.

Serving Style: Regression results supported the hypothesis "H4: Serving style has positive influence on satisfaction", consistent with previous researches of Lertputtarak (2012), Steptoe et al. (1995), Kim and Eves (2012). A positive coefficient of serving style proves a positive relationship between this attribute with satisfaction.

Vendors/Restaurant Staffs: Regression results supported the hypothesis "H5: Vendors/ Restaurant staffs has positive influence on satisfaction", consistent with previous researches of Lertputtarak (2012), Kim and Eves (2012). A positive coefficient of vendors/ restaurant staffs proves a positive relationship between this attribute with satisfaction. 
Recommendation and Revisit Intentions: Regression results supported the hypothesis "H6: Satisfaction has positive influence on recommendation and revisit intentions" was supported. A positive coefficient of satisfaction proves a positive relationship between this attribute with recommendation and revisit intentions.

The relationships between the attributes showed in the model framework were also well studied. Comparing with the reviewed theory and model framework, the data findings proved all hypothesis set. Five chosen attributes of food image have strongly positive impact on food satisfaction of tourists (Namkung \& Jang, 2008; Kim \& Eves, 2012; Lertputarak, 2012). Then the overall satisfaction creates impact on decision of recommendation and revisit of tourists (Chi et al., 2013). The presented model showed $76.2 \%$ variance in satisfaction. Compared with some others variance numbers in previous researches (72.3\% from Tan et al., 2014; 59.51\% from Chi et al., 2013), it can be concluded that the model performed well in predicting food satisfaction of tourists.

\section{Conclusions and Recommendations}

This study aims to gain deeper knowledge about the satisfaction of foreign tourists with the food image of local foods in Ho Chi Minh city which leads to their behavioral intentions. The food image was specially focused. Five attributes of food image were chosen for the research, being taste, health concern, price, serving style and vendors/restaurant staffs. All of these attributes showed a positive relationship with satisfaction. Among five factors, taste had the most impact on food satisfaction. This result is consistent with findings for food image from Kim and Eves (2012), and Namkung and Jang (2008).

Through the analysis of several attributes of food images, this study provides managerial implications for tourism marketers in researching the positive influence of food image on tourists' satisfaction which leads to their positive word-of-mouth and return to the tourism place.

Based on the survey result as well as tourists' feedback, the researcher proposed some below recommendations for tourism marketers:

Design more special marketing program to promote local foods: To attract foreign tourists, more marketing campaign should be launched through media channels. The image of local foods should be created based on their attributes (tastiness, freshness, lots of choices, healthiness, with a worthy value, special serving style). An official website or magazine for local foods experience in Ho Chi Minh city can be considered as the official source for necessary and trustworthy information. Also, marketers should focus to motivate tourists to try local foods during their trip by organize food festivals, cooking class or food testing events.

Cooks/ chefs training: as per the research result, food taste plays the most important role in affecting tourists' satisfaction. Thus, keeping the traditional taste to show the destination identity and to enrich tourist' experiences is significantly important for cooks and restaurant chefs. Thus, tourism marketers should encourage cooks and chefs to participate in knowledge and skill trainings to produce better food products in terms of taste, appearance, smell.

Food safety training and supervising: Food safety is now a big concern, not only for foreign tourists but also for local Vietnamese people. According to the research result in term of health concern, the origin of food ingredients, the environment of food place strongly affects to food quality and satisfaction. Thus, the authorities should pay more attention to the solutions of supervision the cooking process and ingredients' origin.

\section{References}

Al-Ababneh, M. (2013). Service quality and its impact on tourist satisfaction. Interdisciplinary Journal of Contemporary Research in Business, 4(12), 164-177.

Ardabili, F. S., Rasouli, E., Daryani, S. M., Molaie, M., \& Sharegi, B. (2011). The role of food and culinary condition in tourism industry. Middle-East Journal of Scientific Research, 9(6), 826-833.

Baker, D. A., \& Crompton. J. L. (2000). Quality, satisfaction and behavioral intentions. Annals of Tourism Research, 27(3), 785-804.

Chi, G. Q., Chua, B. L, Othman, M., \& Karim, S. A. (2013). Investigating the structural relationships between food image, food satisfaction, culinary quality and behavioral intentions: The case of Malaysia. International Journal of Hospitality \& Tourism, 14, 99-120.

Chi, G. Q., \& Qu, H. (2008). Examining the structural relationships between destination image, tourist satisfaction and destination loyalty: An integrated approach. Journal of Tourism Management, 29(4), 624636.

Chen, C. F., \& Tsai, D. C. (2007). How destination image and evaluative factors affect behavioral intentions? Tourism Management, 28, 1115-1122.

Choi, T. Y., \& Chu, R. (2001). Determination of hotel guests' satisfaction and repeat patronage in the Hong Kong hotel industry. International Journal of Hospitality Management, 20(3), 277-297.

Cohen, E., \& Avieli, N (2004). Food in tourism: Attraction and impediment. Annals of Tourism Research,31(4),755778. 
Frochot, I. (2003). An analysis of regional positioning and its associated food images in French tourism regional brochures. Journal of Travel \& Tourism Marketing, 14(3-4), 77-96.

Jaiswal, G. S., Sapra, N., Patil, J. A., \& Lama, N. (2013). A study on the precursors for gastronomic satisfaction of tourists in Malaysia. Journal of Social and Development Science, 4(1), 6-15.

Jang, S., \& Feng, R. (2007). Temporal destination revisit intention: The effects of novelty seeking and satisfaction. Journal of Tourism Satisfaction, 28(2), 580-590.

Johns, N., \& Pine, R. (2002). Consumer behaviour in the food service industry: A review. International Journal of Hospitality Management, 21(2), 119-134.

Gagic, S., Tesanovic, D., \& Jovicic, A. (2013). The vital components of restaurant quality that affect guest satisfaction. Turizam, 17(4), 166-176.

Kim, H. J., Lee, C. K., Kim, M. J. \& Ryu, K. (2011). Restaurant healthy food quality, perceived value and revisit intentions: Testing a moderating role of green customers in South Korea. International CHRIE Conference, July 2011. Denver, Colorado, USA.

Kim, Y. G., Eves, A., \& Scarles, C. (2009). Building a model of local food consumption on trips and holidays: A grounded theory approach. International Journal of Hospitality Management, 28, 423-431.

Kim, Y. G., \& Eves, A. (2012). Construction and validation of a scale to measure tourist motivation to consume local food. Tourism Management, 33(12), 1458-1467.

Kivela, J., Inbakaran, R., \& Reece, J. (2000). Consumer research in the restaurant environment. Part 3: analysis, findings and conclusions. International Journal of Contemporary Hospitality Management, 12(1), 13-30.

Kozak, M. (2001). Repeaters' behavior at two distinct destinations. Annals of Tourism Research, 28(3), 784-807.

Lertputtarak, S. (2012). The relationship between Destination image, Food image, and Revisiting Pattaya, Thailand. International Journal of Business and Management, 7(5), 111-123.

Ilbery, B., Saxena, G., \& Kneafsey, M. (2007). Exploring tourists and gatekeepers' attitudes towards integrated rural tourism in the England-Wales border region. Tourism Geographies, 9(4), 441-468.

Mak, A. H. N., Lumbers, M., \& Eves, A. (2012). Globalization and food consumption in tourism. Annals of Tourism Research, 39(1), 171-196.

Mitchell, R.D., \& Hall, C. M. (2006). Wine tourism research: The state of play. Tourism Review International, 9(4), 307-332.
Namkung, Y., \& Jang, S. (2007). Does food quality really matter in restaurants? Its impact on customer satisfaction and behavioral intentions. Journal of Hospitality and Tourism Research, 31(3), 387-410.

Nummedal, M., \& Hall, C. M. (2006). Local food in tourism: An investigation of the New Zealand South Island's bed and breakfast sector's use and perception of local food. Tourism Review International, 9(4), 365-378.

Okumus, B. F., \& McKercher, B. (2007). Incorporated local and international cuisines in the marketing of tourism destinations: The case of Hong Kong and Turkey. Journal of Tourism Management, 28(1), 253-261.

Rahman, A., Kalam, A., Rahman, M., \& Abdullah, A. (2012). The influence of service quality and price on customer satisfaction: An empirical study on restaurant service in Khulna division. Research Journal of Finance and Accounting, 3(5), 25-34.

Ryu, K., \& Jang, S. C. (2006). Intention to experience local cuisine in a travel destination: The modified theory of a reasoned action. Journal of Hospitality and Tourism Research, 30(4), 507-516.

Sanchez, J., Callarisa, L., Rodriguez, R. M., \& Moliner, M.A (2006). Perceived value of the purchase of a tourism product. Tourism Management, 27(6), 394-409.

Sims, R. (2009). Food, place and authenticity: local food and the sustainable tourism experience. Journal of Sustainable Tourism, 17(3), 321-336.

Steptoe, A., Pollard, T. M., \& Wardle, J. (1995)., Development of a measure of the motives underlying the selection of food: The food choice questionnaire. Appetite, 25, 267-284.

Tan, Q., Oriade, A., \& Fallon, P. (2014). Service quality and customer satisfation in Chinese fast food sector: A proposal for CFFRSERV. An International Journal of Akdemiz University Tourism Faculty, 2(1), 30-53.

World Tourism Organization (2012). Global Report on Food Tourism. Retrieved from http://cf.cdn.unwto.org/sites/ all/files/pdf/food_tourism_ok.pdf

Yoon, Y., \& Uysal, M. (2005). An examination of the effect of motivation and satisfaction on destination loyalty: A structural model. Journal of Tourism Management, 26(5), 45-56.

Zainal, A., Zali, A. N., \& Kassim, M. N. (2010), Malaysian gastronomy routes as a tourist destination. Journal of Tourism, Hospitality and Culinary Arts, 2, 15-24.

Zeithaml, V. A., Berry, L. L., \& Parasuraman, A. (1996). The behavioral consequences of service quality. Journal of Marketing, 60(2), 31-46. 